HARVARD UNIVERSITY.

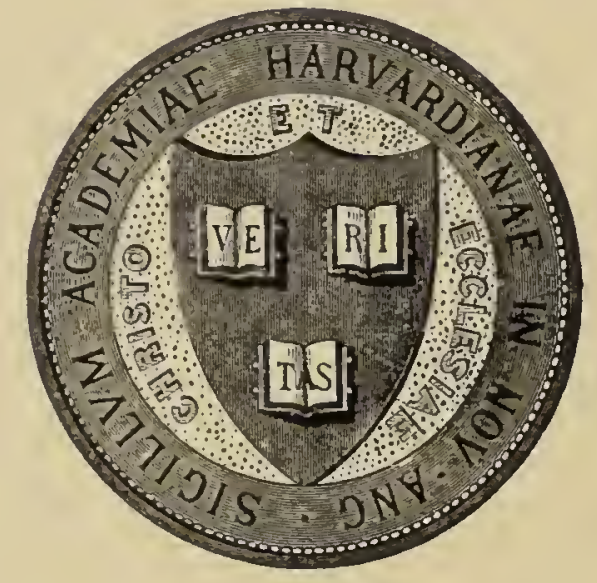

LIBRARY

OF THE

MUSEUM OF COMPARATIVE ZOÖLOGY 58,425

BEquest OF

WALTER FAXON

fanuary 14, 1922 
AMONG THE BIRDS OF THE YOSEMITE.

BY

JOMN MUIR.

ATLANTIC MONTHLY, VOLILXXXII. NO. 494.

DEC. 1898 



\section{AMONG THE BIRDS OF 'THE YOSEMITE.}

Travelers in the Sierra forests usually complain of the want of life. "The trees," they say, "are fine, but the empty stillness is deadly; there are no animals to be seen, no birds. We have not heard a song in all the woods." And no wonder! They go in large parties with mules and horses; they make a great noise; they are dressed in outlandish, unnatural colors: every animal shuns them. Even the frightened pines would run away if they could. But Nature lover's, devout, silent, open-eyed, looking and listening with love, find no lack of inhabitants in these mountain mansions, and they come to them gladly. Not to mention the large animals or the small insect people, every waterfall has its ouzel and every tree its squirrel or tamias or bird : tiny nuthatch threading the furrows of the bark, cheerily whispering to itself as it deftly pries off loose scales and examines the curled edges of lichens; or Clarke crow or jay examining the cones; or some singer - oriole, tanager, warbler - resting, feeding, attending to domestic affairs. Hawks and eagles sail overhead, grouse walk in happy flocks below, and song sparrows sing in every bed of chaparral. There is no crowding, to be sure. Unlike the low Eastern trees, those of the Sierra in the main forest belt average nearly two hundred feet in height, and of course many birds are required to make much show in them and many voices to fill them. Nevertheless, the whole range from foothills to snowy summits is shaken into song every summer; and though low and thin in winter, the music never ceases.

The sage cock - Centrocercus urophasianus - is the largest of the Sierra game-birds and the king of American grouse. It is an admirably strong, hardy, liandsome, independent bird, able with comfort to bid defiance to heat, cold, drought, hurger, and all sorts of storms, living on whatever seeds or insects chance to come in its way, or simply on the leaves of sage-brush, everywhere abundant on its desert range. In winter, when the temperature is oftentimes below zero, and heavy snowstorms are blowing, he sits beneath a sage bush and allows himself to be covered, poking his head now and then through the snow to feed on the leaves of his shelter. Not even the Arctic ptarmigan is hardier in braving frost and snow and wintry darkness. When in full plumage he is a beautiful bird, with a long, firm, sharp-pointed tail, which in walking is slightly raised and swings sidewise back and forth with each step. The male is handsomely marked with black and white on the neck, back, and wings, weighs five or six pounds, and measures about thirty inches in length. The female is clad mostly in plain brown, and is not so large. They occasionally wander from the sage plains into the open nut-pine and juniper woods, but never enter the main coniferous forest. It is only in the broad, dry, half-desert sage plains that they are quite at home, where the weather is blazing hot in summer, cold in winter. If any one passes through a flock, all squat on the gray ground and hold their heads low, hoping to escape observation ; but when approached within a rod or so, they rise with a magnificent burst of wing-beats, looking about as big as turkeys and making a noise like a whirlwind.

On the 28th of June, at the head of Owen's Valley, I caught one of the young that was then just able to fly. It was seven inches long, of a uniform gray color, blunt-billed, and when captured cried lustily in a slirill piping voice, clear in tone as a boy's small willow whistle. I lave seen flocks of from ten to thirty or forty on the eastmargin of the park, 
where the Mono Desert meets the gray foothills of the Sierra; but since cattle have been pastured there they are becoming rarer every yeas.

Another magnificent bird, the blue or dusky grouse, next in size to the sage cock, is found all through the main forest belt, though not in great numbers. They like best the heaviest silver-fir woods near garden and meadow openings, where there is but little underbrush to cover the approach of enemies. When a flock of these brave birds, sauntering and feeding on the sunny flowery levels of some hidden meadow or Yosemite valley far back in the heart of the mountains, see a man for the first time in their lives, they rise with hurried notes of surprise and excitement and alight on the lowest branches of the trees, wondering what the wanderer may be, and showing great eagerness to get a good view of the strange vertical animal. Knowing nothing of guns, they allow you to approach within a half dozen paces, then quietly hop a few branches higher or fly to the next tree without a thought of concealment, so that you may observe them as long as you like, near enough to see the fine shading of their plumage, the feathers on their toes, and the innocent wonderment in their beautiful wild eyes. But in the neighborhood of roads and trails they soon become shy, and when disturbed fly into the highest, leafiest trees, and suddenly become invisible, so well do they know how to hide and keep still and make use of their protective coloring. Nor can they be easily dislodged ere they are ready to go. In vain the hunter goes round and round some tall pine or fir into which he has perhaps seen a dozen enter, gazing up through the branches, straining his eyes while his gun is held ready; not a feather can he see unless his eyes have been sharpened by long experience and knowledge of the blue grouse's habits. 'Then, perhaps, when he is thinking that the tree must be hollow and that the birds have all gone inside, they burst forth with a startling whir of wing-beats, and after gaining full speed go skating swiftly away through the forest arches in a long, silent, wavering slide, with wings held steady.

During the summer they are most of the time on the ground, feeding on insects, seeds, berries, etc., around the margins of open spots and rocky moraines, playing and sauntering, taking sun baths and sand baths, and drinking at little pools and rills during the heat of the day. In winter they live mostly in the trees, depending on buds for food, sheltering beneath dense overlapping branches at night and during storms on the leeside of the trunk, sunning themselves on the southside limbs in fine weather, and sometimes diving into the mealy snow to flutter and wallow, apparently for exercise and fun.

I have seen young broods running beneath the firs in June at a height of eight thousand feet above the sea. On the approach of danger, the mother with a peculiar cry warns the helpless midgets to scatter and hide beneath leaves and twigs, and even in plain open places it is almost impossible to discover them. In the meantime the mother feigns lameness, throws herself at your feet, kicks and gasps and flutters, to draw your attention from the chicks. The young are generally able to fly about the middle of July; but even after they can fly well they are usually advised to run and hide and lie still, no matter how closely approached, while the mother goes on with her loving, lying acting, apparently as desperately concerned for their safety as when they were featherless infants. Sometimes, however, after carefully studying the circumstances, she tells them to take wing; and up and away in a blurry birr and whir they scatter to all points of the compass, as if blown up witl gunpowder, dropping cunningly out of sight three or four hundred yards off, and keeping quiet until called, after the danger is supposed to be past. If you walk on a little way without manifesting any in- 
clination to hunt them, you may sit down at the foot of a tree near enough to see and hear the happy reunion. One touch of nature makes the whole world kin; and it is truly wonderful how love-telling the small voices of these birds are, and how far they reach through the woods into one another's hear'ts and into ours. The tones are so perfectly human and so full of anxious affection, few mountaineers can fail to be touched by then.

They are cared for until full grown. On the 20th of August, as I was passing along the margin of a garden spot on the liead-waters of the San Joaquin, a grouse rose from the ruins of an old juniper that had been uprooted and brought down by an avalanclie from a cliff overhead. She threw herself at my feet, limped and fluttered and gasped, showing, as I thought, that she had a nest and was raising a second brood. Looking for the eggs, I was surprised to see a strong - winged flock nearly as large as the mother fly up around me.

Instead of seeking a warmer climate when the winter storms set in, these hardy birds stay all the year in the High Sierra forests, and I have never known them to suffer in any sort of weather. Able to live on the buds of pine, spruce, and fir, they are forever independent in the natter of food supply, which gives so many of us trouble, dragging us here and there away from our best work. How gladly I would live on pine buds, however pitchy, for the sake of this grand independence. With all his superior resources, man makes more distracting difficulty concerning food than any other of the family.

The mountain quail or plumed partridge (Oreortyx pictus plumiferus) is common in all the upper portions of the park, though nowhere found in large number's. He ranges considerably highel than the grouse in summer, but is unable to endure the heavy storms of winter. When his food is buried he descends the range to the brushy foothills, VOL. LXXXII. - NO. 494. at a height of from two thousand to three thousand feet above the sea; but like every true mountaineer, he is quick to follow the spring back into the highest mountains. I think he is the very handsomest and most interesting of all the American partridges, larger and handsomer than the famnous Bob White, or even the fine Califormia valley quail or the Massena partridge of Arizona and Mexico. That he is not so regarded, is beeause as a lonely momntineer he is not half known.

His plunnage is delicately shaded, brown above, white and rich chestnut below and on the sides, with many dainty markings of black and white and gray here and there, while his beautiful head plume, three or four inches long, nearly straight, conposed of two feathers closely folded so as to appear as one, is worn jauntily slanted backward like a single feather in a boy's cap, giving him a very marked appearance. They wander over the lonely mountains in family flocks of from six to fifteen, beneath ceanothus, manzanita, and wild cherry thickets, and over dry sandy flats, glacier meadows, rocky ridges, and beds of bryanthus around glacier lakes, especially in autumn when the berries of the upper gardens are ripe, uttering low clucking notes to enable them to keep together. When they are so suddenly disturbed that they are afraid they cannot escape the danger by running into thickets, they rise with a fine hearty whir and scatter in the brush over an area of half a square mile or so, a few of them diving into leafy trees. But as soon as the danger is past, the parents with a clear piping note call them together again. By the end of July the young are two thirds grown and fly well, though only dire necessity can compel them to try their wings. In gait, gestures, habits, and general behavior they are like domestic chickens, but infinitely finer, searching for insects and seeds, looking to this side and that, scratehing among fallen leaves, junping 
up to pull down grass heads, and clucking and muttering in low tones.

Once when $I$ was seated at the foot of a tree on the head-waters of the Merced, sketching, I heard a flock up the valley behind me, and by their voices gradually sounding nearer I knew that they were feeding toward me. I kept still, hoping to see them. Soon one came within three or four feet of ne, without noticing me any nore than if I were a stump or a bulging part of the trunk against which I was leaning, my clothing being brown, nearly like the bark. Presently along came another and another, and it was delightful to get so near a view of these handsome chickens perfectly undisturbed, observe their manners, and hear their low peaceful notes. At last one of them caught my eye, gazed in silent wonder for a moment, then uttered a peculiar cry, which was followed by a lot of hurried muttered notes that sounded like speech. The other's, of course, saw me as soon as the alarm was sounded, and joined the wonder talk, gazing and chattering, astonished but not frightened. Then all with one accord ran back with the news to the rest of the flock. "What is it? what is it? Oh, you never saw the like," they seemed to be saying. "Not a deer, or a wolf, or a bear ; come see, come see." "Where? where?" "Down there by that tree." Then they approached cautiously, past the tree, stretching their necks, and looking up in turn as if knowing from the story told them just where I was. For fifteen or twenty minutes they kept coming and going, venturing within a few feet of me, and discussing the wonder in charming chatter. Their curiosity at last satisfied, they began to scatter and feed again, going back in the direction they had come from; while I, loath to part with them, followed noiselessly, crawling beneath the bushes, keeping them in sight for an hour or two, learning their habits, and finding out what seeds and berries they liked best.
'The valley quail is not a mountaineer', and seldom enter's the park except at a few of the lowest places on the western boundary. It belongs to the brushy foothills and plains, orchards and wheatfields, and is a hundred times more numerous than the mountain quail. It is a beautiful bird, about the size of the Bob White, and has a handsome crest of four or five feathers an inch long, recurved, standing nearly erect at times or drooping forward. The loud calls of these quails in the spring - Pe-checkah, Pe-check-a, Hoy, Hoy - are heard far and near over all the lowlands. They have vastly increased in numbers since the settlement of the country, notwithstanding the immense numbers killed every season by boys and pot-liunters as well as the regular leggined sportsmen from the towns; for man's destructive action is more than counterbalanced by increased supply of food from cultivation, and by the destruction of their enemies - coyotes, skunks, foxes, liawks, owls, etc. - which not only kill the old birds, but plunder their nests. Where coyotes and skunks abound, scarce one pair in a hundred is successful in raising a brood. So well aware are these birds of the protection afforded by man, even now that the number of their wild enemies has been greatly diminished, that they prefer to nest near houses, notwithstanding they are so shy. Four or five pairs rear their young around our cottage every spring. One year a pair nested in a straw pile within four or five feet of the stable door, and did not leave the eggs when the men led the horses back and forth within a foot or two. For many seasons a pair nested in a tuft of pampas grass in the garden; another pair in an ivy vine on the cottage roof, and when the young were hatched, it was interesting to see the parents getting the fluffy dots down. They were greatly excited, and their anxious calls and directions to their many babes attracted our attentiou. They had no great dif- 
ficulty in persuading the young birds to pitch themselves from the main roof to the por'ch roof among the ivy, but to get them safely down from the latter to the ground, a distance of ten feet, was most distressing. It seemed impossible the frail soft things could avoid being killed. The anxious parents led them to a point above a spiræa bush, that reached nearly to the eaves, which they seened to know would break the fall. Anyhow they led their chicks to this point, and with infinite coaxing and encouragement got them to tumble themselves off. Down they rolled and sifted through the soft leaves and panicles to the pavement, and, strange to say, all got away unhurt except one that lay as if dead for a few minutes. When it revived, the joyful parents, with their brood fairly launched on the journey of life, proudly led them down the cottage hill, through the garden, and along an osage orange hedge into the cherry orchard. These charming birds even enter towns and villages, where the gardens are of good size and guns are forbidden, sometimes going several miles to feed, and returning every evening to their roosts in ivy or brushy trees and shrubs.

Geese occasionally visit the park, but never stay long. Sometimes on their way across the range, a flock wanders into Hetch-Hetchy or Yosemite to rest or get something to eat, and if shot at, are often sorely bewildered in seeking a way out. I have seen them rise from the meadow or river, wheel round in a spiral until a height of four or five hundred feet was reached, then form ranks and try to fly over the wall. But $\mathrm{Y}_{0-}$ semite magnitudes seem to be as deceptive to geese as to men, for they would suddenly find themselves against the cliffs not a fourth of the way to the top. Then turning in confusion, and screaming at the strange heights, they would try the opposite side, and so on, until exhausted they were compelled to rest, and only after discovering the river cañon could they make their escape. Large harrow-shaped flocks may often be seen crossing the range in the spring, at a height of at least fourteen thousand feet. Think of the strength of wing required to sustain so heavy a bird in air so thin. At this elevation it is but little over half as dense as at the sea level. Yet they hold bravely on in beautifully dressed ranks, and have breath enough to spare for loud honking. After the erest of the Sierra is passed it is only a smooth slide down the sky to the waters of Mono, where they may rest as long as they like.

Ducks of five or six species, among which are the mallard and wood duck, go far up into the heart of the mountains in the spring, and of course come down in the fall with the families they have reared. A few, as if loath to leave the mountains, pass the winter in the lower valleys of the park at a height of three thousand to four thousand feet, where the main streams are never wholly frozen over, and snow never falls to a great depth or lies long. In summer they are found up to a height of eleven thousand feet on all the lakes and branches of the rivers except the smallest, and those beside the glaciers encumbered with drifting ice and snow. I found mallards and woor ducks at Lake Tenaya, June 1 , before the ice-covering was half melted, and a flock of young ones in Bloody Cañon Lake, June 20. They are usually met in pairs, never in large flocks. No place is too wild or rocky or solitary for these brave swimmers, no stream too rapid. In the roaring, resounding cañon torrents, they seem as much at home as in the tranquil reaches and lakes of the broad glacial valleys. Abandoning themselves to the wild play of the water's, they go drifting confidingly through blinding, thrashing spray, dancing on boulder-dashed waves, tossing in beautiful security on rougher water than is usually encountered by sea birds when storms are blowing. 
A mother duck with her family of ten little ones, waltzing round and round in a pot-hole ornamented with foam bells, luge rocks leaning over them, cascades above and below and beside them, made one of the most interesting bird pictures I ever saw.

I have never found the great northern diver in the park lakes. Mlost of them are inaccessible to him. He might plump down into them, but would hardly be able to get out of them, since, with his small wings and heavy body, a wide expanse of elbow room is required in rising. Now and then one may be seen in the lower Sierra lakes to the north ward about Lassens Butte and Shasta, at a lieight of four thousand to five thousand feet, making the loneliest places lonelier with the wildest of wild cries.

Plovers are found along the sandy shores of nearly all the mountain lakes, tripping daintily on the water's edge, picking up insects; and it is interesting to learn how few of these familiar birds are required to make a solitude cheerful.

Sandhill cranes are sometimes found in comparatively small marshes, mere dots in the mighty forest. In such spots, at an elevation of from six thousand to eight thousand feet above the sea, they are occasionally met in pairs as early as the end of May, while the snow is still deep in the surrounding fir and sugarpine woods. And on sunny days in autumn, large flocks may be seen sailing at a great height above the forests, shaking the crisp air into rolling waves with their hearty koor-r'r', koor-r-1' uck-uck, soaring in circles for hours together on their majestic wings, seeming to float without effort like clouds, eying the wrinkled landscape outspread like a map mottled with lakes and glaciers and meadows, and streaked with shadowy cañons and streams, and surveying every frog marsh and saudy flat within a liundred miles.

Eagles and hawks are oftentimes seen above the ridges and domes. The greatest height at which I have observed them was about twelve thousand feet, over the summits of Mount Hoffman, in the middle region of the park. A few pairs had their nests on the cliffs of this mountain, and could be seen every day in sum mer, hunting marmots, mountain beaver's. pikas, etc. A pair of golden eagles have made their home in Yosemite ever since I went there thirty years ago. Their' nest is on the Nevada Fall Cliff, opposite the Liberty Cap. Their screams are rather pleasant to hear in the vast gulfs between the granite cliffs, and they help the owls in keeping the echoes busy.

But of all the birds of the High Sierra, the strangest, noisiest, and most notable is the Clarke crow (Nucifraga columbiana). He is a foot long and nearly two feet in extent of wing, ashy gray in general color, with black wings, white tail, and a strong sharp bill, with which he digs into pine cones for the seeds on which he mainly subsists. He is quick, boisterous, jerky, and irregular in his movements and speech, and makes a tremendously loud and showy advertisement of himself, - swooping and diving in deep curves across gorges and valleys from ridge to ridge, alighting on dead spars, looking warily about him, and leaving his dry springy perches trembling from the vigor of his kick as he launches himself for' a new flight, screaming from time to time loud enough to be heard more than a mile in still weather. $\mathrm{He}$ dwells far back on the high, storm-beaten margin of the forest, where the mountain pine, juniper, and hemlock grow wide apart on glacier pavements and domes and rough crumbling ridges, and the dwarf pine makes a low crinkled growth along the flanks of the summit peaks. In so open a region, of course, he is well seen. Everybody notices him, and nobody at first knows what to make of him. One guesses he must be a woodpecker, another a crow or some sort of jay, another a magpie. He seems to be a pretty thoroughly mixed and fermented compound of all these birds, has all their 
strength, cumning, shyness, thievishness, and wary, suspicious curiosity combined and condensed. He flies like a woodpecker, hammers dead limbs for insects, digs big holes in pine cones to get at the seeds, cracks nuts held between his toes, cries like a crow or Steller jay, - but in a far louder, harsher, and more forbidding tone of voice, - and besides his crow caws and screams, has a great variety of small chatter talk, mostly uttered in a fault-finding tone. Like the magpie, he steals articles that can be of no use to him. Once when I made my camp in a grove at Cathedral Lake, I chanced to leave a cake of soap on the shore where I had been washing, and a few minutes afterward I saw my soap flying past nile through the grove, pushed by a Clarke crow.

In winter, when the snow is deep, the cones of the mountain pines empty, and the juniper, henlock, and dwarf pine orchards buried, he comes down to glean seeds in the yellow pine forests, startling the grouse with his loud screams. But even in winter, in calm weather, he stays in his high mountain home, defying the bitter frost. Once I lay snowbound through a three days' storm at the timber-line on Mount Shasta; and while the roaring snow-laden blast swept by; one of these brave birds came to my camp, and began hammering at the cones on the topmost branches of half-buried pines, without showing the slightest distress. I have seen Clarke crows feeding their young as early as June 19, at a height of more than ten thousand feet, when nearly the whole landscape was snowcovered.

They are excessively shy, and keep away from the traveler as long as they think they are observed; but when one goes on without seeming to notice them, or sits down and keeps still, their curiosity speedily gets the better of their caution, and they come flying from tree to tree, nearer and nearer, and watch every motion. Few, I am afraid. will ever learn to like this bird, he is so suspicious and self-reliant, and his voice is so harsh that to most ears the scream of the eagle will seem melodious compared with it. Yet the mountaineer who has battled and suffered and struggled must admire his strength and endurance, the way he faces the mountain weather, cleaves the icy blasts, cares for his young, and digs a living from the stern wilderness. Higher yet than Nucifraga dwells the little dun-headed sparrow (Leucosticte tephrocotis). From early spring to late autumn he is to be found only on the snowy icy peaks at the head of the glacier cirques and cañons. His feeding grounds in spring are the snow sheets between the peaks, and in midsummer and autumn the glaciers. Many bold insects go mountaineering almost as soon as they are born, ascending the highest summits on the mild breezes that blow in from the sea every day during steady weather; but comparatively few of these adventurers find their way down or see a flower bed again. Getting tired and chilly, they alight on the snow fields and glaciers, attracted perhaps by the glare, take cold, and die. There they lie as if on a white cloth purposely outspread for theni, and the dun sparrows find them a rich and varied repast requiring no pursuit, - bees and butterflies on ice, and many spicy beetles, a perpetual feast, on tables big for guests so small, and in vast banqueting halls ventilated by cool breezes that ruffle the feathers of the fairy brownies. Happy fellows, no rivals come to dispute possession with them. No other birds, not even hawks, as far as I have noticed, live so high. They see people so seldom, they flutter around the explorer with the liveliest curiosity, and come down a little way, sometimes nearly a mile, to meet him and conduct him into their icy homes.

When I was exploring the Merced group, climbing up the grand cañon between the Merced and Red mountains into the fountain amphitheatre of an an- 
cient glacier, just as I was approaching the small active glacier that leans back in the shadow of Merced Mountain, a flock of twenty or thirty of these little birds, the first I had seen, came down the cañon to meet me, flying low, straight toward me as if they meant to fly in my face. Instead of attacking me or passing by, they circled round my head, chirping and fluttering for a minute or two, then turned and escorted me up the cañon, alighting on the nearest rocks on either hand, and flying ahead a few yards at a time to keep even with me.

I have not discovered their winter quarters. Probably they are in the desert ranges to the eastward, for I never saw any of them in Yosemite, the winter refuge of so many of the mountain birds.

Hummingbirds are among the best and most conspicuous of the mountaineers, flashing their ruby throats in countless wild gardens far up the higher slopes, where they would be least expected. All one has to do to enjoy the company of these mountain-loving midgets is to display a showy blanket or handkerchief.

The arctic bluebird is another delightful mountaineer, singing a wild, cheery song and "carrying the sky on his back" over all the gray ridges and domes of the subalpine region.

A fine, hearty, good-natured lot of woodpeckers dwell in the park, and keep it lively all the year round. Among the most notable of these are the magnificent log cock (Ceophlcens pileatus), the prince of Sierra woodpeckers, and only second in rank, as far as I know, of all the woodpeckers of the world; the Lewis woodpecker, large, black, glossy, that flaps and flies like a crow, does but little hammering, and feeds in great part on wild cherries and berries; and the carpenter, who stores up great quantities of acorns in the bark of trees for winter use. The last uamed species is a beautiful bird, charmingly familiar and far more common than the others. In the woods of the West he represents the eastern red-head. Bright, cheerful, industrious, not in the least shy, the carpenters give delightful animation to the open Sierra forests at a height of from three thousand to fifty-five hundred feet, especially in autumn when the acorns are ripe. Then no squirrel works harder at his pine-nut harvest than these wood. peckers at their acorn harvest, drilling holes in the thick, corky bark of the yellow pine and incense cedar, in which to store the crop for winter use; a hole for each acorn, so nicely adjusted as to size that when the acorn, point foremost, is driven in, it fits so well that it cannot be drawn out without digging around it. Each acorn is thus carefully stored in a dry bin, perfectly protected from the weather, - a most laborious method of stowing away a crop, a granary for each kernel. Yet the birds seem never to weary at the work, but go on so diligently that they seem determined to save every acorn in the grove. 'They are never seen eating acorns at the time they are storing them, and it is commonly believed that they never eat them or intend to eat them, but that the wise birds store then and protect them from the depredations of squirrels and jays, solely for the sake of the worms they are supposed to contain. And because these worms are too small for use at the time the acorns drop, they are shut up like lean calves and steers, each in a separate stall with abundance of food, to grow big and fat by the time they will be most wanted, that is, in winter, when insects are scarce and stall-fed worms most valuable. So these woodpeckers are supposed to be a sort of cattle-raisers, each with a drove of thousands, rivaling the ants that raise grain and keep herds of plant lice for milk cows. Needless to say the story is not true, though some naturalists even believe it. When Emerson was in the park, having heard the worm story and seen the great pines plugged full of acorns. he asked (just to pump me, 
I suppose), "Why do the woodpeckers take the trouble to put acorns into the bark of the trees?" "For the same reason," I replied, "that bees store honey and squirrels nuts." "But they tell me, Mr. Murir, that woodpeckers don't eat acorns." "Yes, they do," I said, "I have seen them eating them. During snowstorms they seem to eat little besides acorns. I lave repeatedly interrupted them at their meals, and seen the perfectly sound, half-eaten acorns. They eat them in the shell as some people eat eggs." "But what about the worms?" "I suppose," I said, "that when they come to a wormy one they eat both worm and acorn. Anyhow, they eat the sound ones when they can't find anything they like better, and from the time they store them until they are used they guard them, and woe to the squirrel or jay caught stealing." Indians, in times of scarcity, frequently resort to these stores and chop them out with hatchets; a bushel or more may be gatliered from a single cedar or pine.

The common robin, with all his familiar notes and gestures, is found nearly everywhere throughout the park, - in shady dells beneath dogwoods and maples, along the flowery banks of the streams, tripping daintily about the margins of meadows in the fir and pine woods, and far beyond on the shores of glacier lakes and the slopes of the peaks. How admirable the constitution and temper of this cheery, graceful bird, keeping glad health over so vast and varied a range. In all America he is at lome, flying from plains to mountains up and down, north and south, away and back, with the seasons and supply of food. Oftentimes, in the High Sierra, as you wander through the solemn woods, awe-stricken and silent, you will hear the reassuring voice of this fellow wanderer ringing out sweet and clear as if saying, "Fear not, fear" not. Only love is liere." In the severest solitudes he seems as happy as in gardens and apple orchards.
The robins enter the park as soon as the snow melts, and go on up the mountains, gradually higher, with the opening flowers, until the topmost glacier meadows are reached in June and July. After the short summer is done, they descend like most other summer visitors in concord with the weather, keeping out of the first heavy suows as much as possible, while lingering among the frost-nipped wild cherries on the slopes just below the glacier meadows. 'Thence they go to the lower slopes of the forest region, compelled to make laste at times by lieavy all-day storms, picking up seeds or benumbed insects by the way, and at last all, save a few that winter in Yosemite valleys, arrive in the vineyards and orchards and stubble-fields of the lowlands in November, picking up fallen fruit and grain, and awakening old-time memories among the white-headed pioneers, who cannot fail to recognize the influence of so homelike a bird. They are then in flocks of hundreds, and make their way into the gardens of towns as well as into the parks and fields and orchards about the bay of San Francisco, where many of the wanderers are shot for sport and the morsel of meat on their breasts. Man then seems a beast of prey. Not even genuine piety can make the robin-killer quite respectable. Saturday is the great slaughter day in the bay region. Then the city pot-hunters, with a ragtag of boys, go forth to kill, kept in countenance by a sprinkling of regular sportsmen arrayed in selfconscious majesty and leggins, leading dogs and carrying hammerless, breechloading guns of famous makers. Orer the fine landscapes the killing goes for ward with shameful enthusiasm. After escaping countless dangers, thousands fall, big bagfuls are gathered, many are left wounded to die slowly, no Red Cross Society to help them. Next day, Sunday, the blood and leggins vanish from the most devout of the bird butchers. who go to church. carrying gold-headed 
canes instead of guns. After hymns, prayers, and sermon they go home to feast, to put God's songbirds to use, put them in their dinner's instead of in their hearts, eat them, and suck the pitiful little drumsticks. It is only race living on race, to be sure, but Christians singing Divine Love need not be driven to such straits while wheat and apples grow and the shops are full of dead cattle. Songbirds for food! Compared with this, making kindlings of pianos and violins would be pious economy.

The larks come in large flocks from the hills and mountains in the fall, and are slaughtered as ruthlessly as the robins. Fortunately, most of our songbirds keep back in leafy hidings, and are comparatively inaccessible.

The water ouzel, in his rocky home amid foaming waters, seldom sees a gun, and of all the singers I like him the best. He is a plainly dressed little bird, about the size of a robin, witl short, crisp, but rather broad wings, and a tail of moderate length, slanted up, giving him with his nodding, bobbing manners a wrennish look. He is usually seen fluttering about in the spray of falls and the rapid cascading portions of the main branches of the rivers. These are his favorite haunts; but he is often seen also on comparatively level reaches and occasionally on the shores of mountain lakes, especially at the beginning of winter, when heavy snowfalls have blurred the streams with sludge. Though not a water bird in structure, he gets lis living in the water, and is never seen away from the immediate margin of streams. $\mathrm{He}$ dives fearlessly into rough, boiling eddies and rapids to feed at the bottom, flying under water seemingly as easily as in the air. Sometimes he wades in shallow places, thrusting his head under from time to time in a nodding, frisky way that is sure to attract attention. His flight is a solid whir of wing-beats like that of a partridge, and in going from: place to place along his favorite string of rapids he follows the windings of the stream, and usually alights on some rock or suag on the bank or out in the current, or rarely on the dry limb of an overhanging tree, perching like a tree bird when it suits his convenience. $\mathrm{He}$ has the oddest, neatest manner's imaginable, and all his gestures as he flits about in the wild, dashing waters bespeak the utmost cheerfulness and confidence. He sings both winter and summer, in all sorts of weather, - a sweet, fluty melody, rather low, and much less keen and accentuated than from the brisk vigor of his movements one would be led to expect.

How romantic and beautiful is the life of this brave little singer on the wild mountain streams, building his round bossy nest of moss by the side of a rapid or fall, where it is sprinkled and kept fresh and green by the spray! Nowonder he sings well, since all the air about him is music; every breath he draws is part of a song, and he gets his first music lessons before he is born; for the eggs vibrate in time with the tones of the waterfalls. Bird and stream are inseparable, songful and wild, gentle and strong, - the bird ever in danger in the midst of the stream's mad whirlpools, yet seeming immortal. And so I might go on, writing words, words, words; but to what purpose? Go see him and love him, and through him as through a window look into Nature's warm heart.

John Muir. 
, 



\section{$-30$}

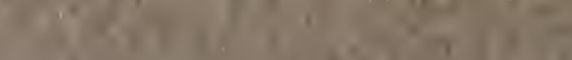

